Наносистели, нанолатеріали, нанотехнології Nanosistemi, Nanomateriali, Nanotehnologii 2020, т. 18, № 3, сc. 631-637 (c) 2020 IМФ (Інститут металофізики ім. Г. В. Курдюмова НАН України) Надруковано в Україні. Фотокопіювання дозволено тільки відповідно до ліцензії

PACSnumbers: 36.40.Vz, 61.46.Df, 78.30.Na, 78.40.Ri, 78.55.Kz, 78.67.Hc, 81.07.Ta

\title{
Heating-Induced Photoluminescence-Tuneable Carbon Dots Synthesized From Aloe Vera Gel
}

\author{
Elisabeth Pratidhina ${ }^{1,2}$, Sabaruddin ${ }^{1}$, Riki Perdana ${ }^{1}$, Heru Kuswanto ${ }^{1}$, \\ and Wipsar Sunu Brams Dwandaru ${ }^{1}$ \\ ${ }^{1}$ Yogyakarta State University, \\ Colombo No. 1 Rd., \\ Yogyakarta, Indonesia \\ ${ }^{2}$ Department of Physics Education, \\ Widya Mandala Catholic University, \\ 42-44, Dinoyo Str., \\ 60236 Surabaya, East Java, Indonesia
}

Along with quantum dots (QD), carbon dots (CDs) have attracted a lot of attention due to its strong optical properties and simple synthesis procedure. For decades, Aloe vera has been used for medical and cosmetic applications. Another application of Aloe vera is reported here; we have synthesized CDs from Aloe vera gel through a simple heating process. With variation of heating duration, we achieved CDs with various photoluminescence (PL) properties. The variation of heating duration has changed the functional group on the CDs surface and induces tuneable PL properties. In this paper, we present three types of CDs, i.e., blue, green, and yellow CDs with PL peak at wavelength of at 438,503 , and $614 \mathrm{~nm}$, respectively.

Поряд з квантовими точками (QD), вуглецеві точки (CDs) привернули велику увагу завдяки своїм сильним оптичним властивостям і простій процедурі синтези. Протягом десятиліть алое вера використовувалася для медичного та косметичного застосування. Ще одне застосування алое вера повідомляється тут; ми синтезували вуглецеві точки з ґелю алое вера через простий процес нагрівання. 3 варіяцією тривалости нагрівання ми досягли вуглецеві точки з різними фотолюмінесцентними (PL) властивостями. Варіяція тривалости нагрівання змінила функціональну групу на поверхні вуглецевих точок і викликає фотолюмінесцентні властивості з підстроюванням. У цій роботі ми представляємо три типи вуглецевих точок, тобто сині, зелені та жовті вуглецеві точки з піком фотолюмінесценції на довжині хвилі 438, 503 та 614 нм відповідно.

Key words: carbon dots, photoluminescence, tunability, heating, Aloe vera. 
Ключові слова: вуглецеві точки, фотолюмінесценція, регульованість, нагрівання, гель Aloe vera.

(Received 3 January, 2020; in revised form, 13 January, 2020)

\section{INTRODUCTION}

In recent decades, quantum dots (QDs) have attracted much attention due to its superior optical properties. The superior optical properties are caused by the quantum confinement effect in zero-dimension material, which cannot be found in the bulk counterparts or single atom. QD is a promising material for display [1, 2], solar cell [3, 4], imaging [5], and sensing [6].

In accordance with quantum dot materials, recently carbon quantum dots or carbon dots (CDs) rise in popularity. CDs are zero-dimension carbon nanomaterial; its size is less than 10 nanometers. CDs have been studied extensively due to their attractive properties such as strong optical properties [7], high stability [8], low toxicity [9], environmentally friendly, and simple synthesis procedure [10]. The properties of CDs allow various applications such as bio-imaging [11], sensing [12, 13], bio-medicine [14], light-emitting diode [15], catalyst [16], and optoelectronics devices [17].

Besides its attractive optical properties, another advantage of CDs is they can be synthesized in simple way with cheap raw materials [10]. The synthesis of CDs using bio-mass has been studied extensively, as well as synthesizing CDs from coconut shell [18], sugar cane [19], gooseberries [20], and seeds [21].

According to the theoretical prediction, the properties of CDs can be tuned by varying its size or passivating CDs surface with other elements [22]. One challenging issue is tuning the photo luminesce (PL) properties of CDs from the same raw material through the same method. CDs with tuneable and high PL is suitable for biological labelling and imaging applications [23].

Aloe vera leaf gel contains anthrones, carbohydrates (pure mannan, acetylated mannan, acetylated glucomannan, glucogalactomannan, galactan, galactogalacturan, arabinogalactan, galactoglucoarabinomannan, pectic substance, xylan, cellulose), chromosome (8-Cglucosyl-(2'-O-cinnamoyl)-7-O-methylaloediol A and 8-C-glucosyl-(S)aloesol), enzyme (Alkaline phosphatase, amylase, carboxypeptidase, catalase, cyclooxidase, and cyclooxygenase), inorganic compounds (Calcium, chlorine, chromium, copper, iron, magnesium, manganese, potassium, phosphorous, sodium, and zinc), proteins such as lectin, polysaccharides, and vitamins [24]. Aloe vera is known for its antioxidant, antimicrobial, antiseptic, antibacterial, and anti-inflammatory properties. The Aloe vera plant has been used for centuries for its 
health, beauty, medicinal, and skincare properties [25]. In this article, we show other applications of Aloe vera gel, i.e., as a primary precursor for CDs synthesis with tuneable PL properties.

\section{METHOD}

\subsection{Synthesis of CDs}

The CDs were prepared by heating the mixture of Aloe vera gel, distilled water, and phosphoric acid. Typically, we mixed 12 grams of Aloe vera gel, $5 \mathrm{~mL}$ distilled water, and $15 \mathrm{~mL}$ of concentrated phosphoric acid. The mixture was heated on hot plate with average temperature of $99^{\circ} \mathrm{C}$ for various times. In this research, the heating duration was varied, i.e., 60, 90, and 120 minutes. After the mixture is heated for a particular time, the mixture colour will turn to dark brown and then black. The mixture is then dispersed in $100 \mathrm{~mL}$ distilled water for 20 hours. After that, the solutions were filtrated using a filter membrane.

\subsection{CDs Characterization}

As prepared CDs, solutions are characterized using photoluminescence (PL), Ultraviolet-Visible (UV-Vis), and Fourier-transform infrared (FT-IR) spectroscopy analysis. UV-Vis spectrophotometric analysis is carried out on a Shimadzu UV 1800 spectrophotometer. PL spectroscopy is conducted using custom-configured device with Ocean Optics USB4000 spectrometer. The FT-IR spectroscopy is performed using FTIR Thermo Nicolet Avatar 360.

\section{RESULTS AND DISCUSSIONS}

In this study, we have synthesized three types of CDs, i.e., blue, green, and yellow CDs. The names are taken based on the CDs luminescence under UV illumination (such as shown in Figure 1, $a-c$ inset). All of the CDs are produced from Aloe vera gel mixed with concentrate $\mathrm{H}_{3} \mathrm{PO}_{4}$ and distilled water, which is heated at average temperature of $99^{\circ} \mathrm{C}$. Variation of heating duration in the synthesis process produce different types of CDs. The blue, green, and yellow CDs are produced through $2.5,2$, and 1 hour(s) of heating, respectively.

The CDs absorbance responses to light with various wavelengths have been studied through UV-Vis spectrophotometric analysis (Figure 1). The synthesized blue CD has absorbance peak at $244 \mathrm{~nm}$. It corresponds to the $\pi-\pi^{*}$ transition coming from the $\mathrm{C}=\mathrm{C}$ bonding of the $\mathrm{CD}$ core. For the green CDs, there is shoulder peak of absorbance around $260 \mathrm{~nm}$. Meanwhile, peaks appear two times in yellow CDs, i.e., 

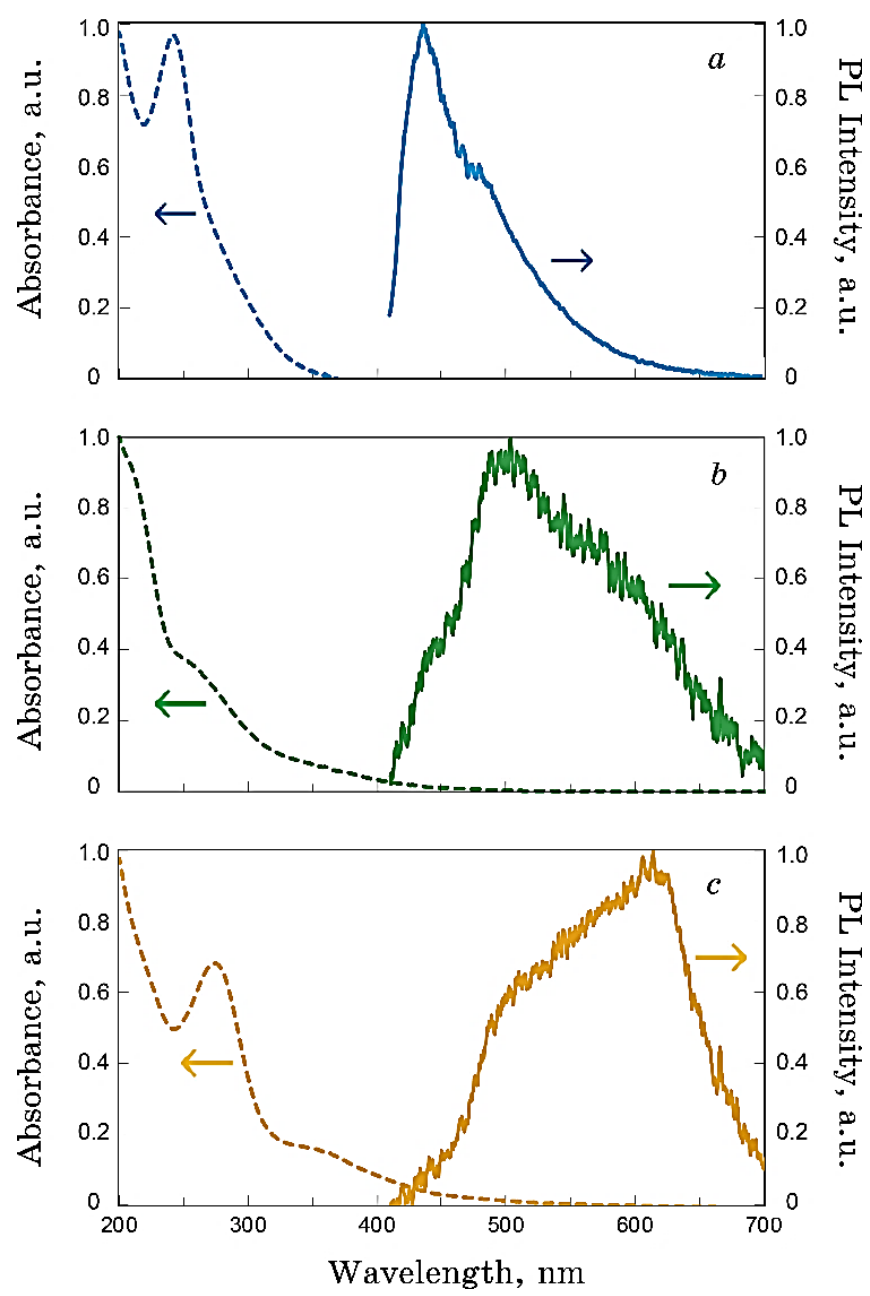

Fig. 1. Normalized PL emission spectra (bold line), absorbance spectra (dashed line), and photo of ( $a$ ) blue-CD, $(b)$ green-CD, and $(c)$ yellow-CD under UV light illumination. The emission spectra were obtained at an excitation wavelength of $410 \mathrm{~nm}$.

at 278 and $368 \mathrm{~nm}$. Absorbance peak at $278 \mathrm{~nm}$ in yellow CDs corresponds to the $\pi-\pi^{*}$ transition coming from the $\mathrm{C}=\mathrm{C}$ bonding of the CD core. Whereas the other peak seems to come from the transition in the surface or edge state. Overall, from yellow to blue CDs, the absorbance peak shifted to smaller wavelength.

PL emission spectra of the blue, green, and yellow CDs are also depicted in Fig. 1. The PL emissions of blue, green, and yellow CDs have peaks at 438, 503, and $614 \mathrm{~nm}$, respectively. It indicates blue shifting of PL peak arises as we increase the heating duration on the synthesis 
process.

The functional groups of CDs are characterized by FT-IR study. As shown in Fig. 2, blue CDs and yellow CDs have similar absorption bands. For blue CDs, absorption bands appear at 3430, 2360, 1639, 1176 , and $1003 \mathrm{~cm}^{-1}$ that corresponds to $\mathrm{O}-\mathrm{H}, \mathrm{O}=\mathrm{C}=\mathrm{O}, \mathrm{C}=\mathrm{C}, \mathrm{S}=\mathrm{O}$, and $\mathrm{C}-\mathrm{O}$ functional group, respectively. For yellow $\mathrm{CDs}$, absorption bands appear at $3447,2384,1640,1175$, and $1006 \mathrm{~cm}^{-1}$, which also corresponds to $\mathrm{O}-\mathrm{H}, \mathrm{O}=\mathrm{C}=\mathrm{O}, \mathrm{C}=\mathrm{C}, \mathrm{S}=\mathrm{O}$, and $\mathrm{C}-\mathrm{O}$ functional group, respectively. Although it is weak, the peak correspond to $\mathrm{C}-\mathrm{H}$ bond also can be seen in both yellow and blue CDs. In the FT-IR spectrum, yellow CDs show more existence of $\mathrm{O}=\mathrm{C}=\mathrm{O}, \mathrm{C}-\mathrm{O}$, and $\mathrm{C}-\mathrm{H}$ bonds, which may be exist in the edge of CDs. It is consistence to the UV-Vis spectrum, in which yellow CDs have secondary absorption peak at $368 \mathrm{~nm}$. This absorption comes from the presence of hydrogen on the surface of yellow CDs.

We observe that longer heating duration causes the UV-Vis absorption peak shift to shorter wavelength. It indicates that the bandgap en-

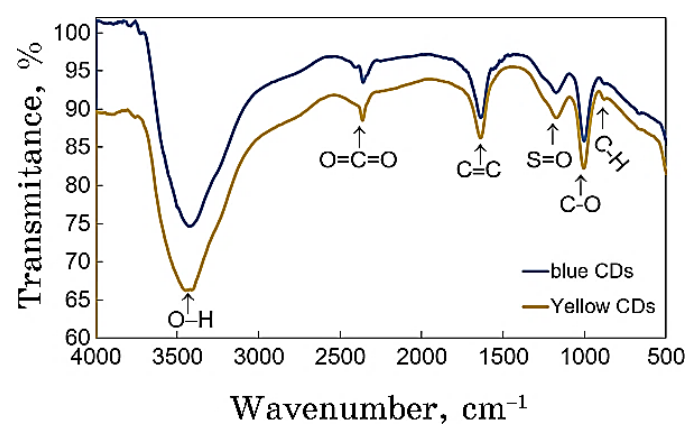

Fig. 2. FT-IR Spectrum of yellow and blue CDs synthesized from Aloe vera.

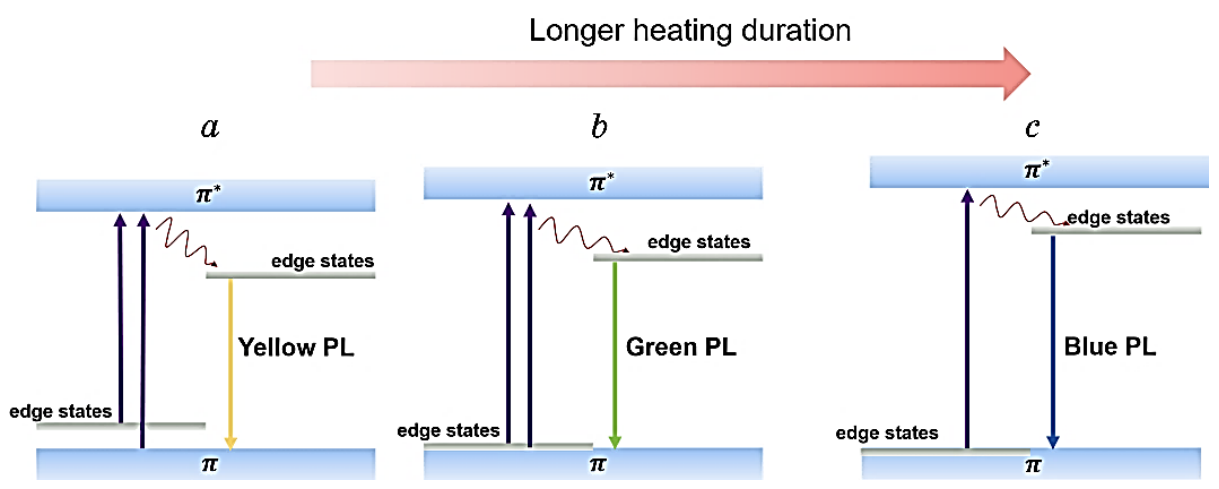

Fig. 3. Schematic diagram of energy band in the $(a)$ yellow, $(b)$ green, and blue CDs $(c)$. 
ergy increases as the heating process becomes longer. An increase in bandgap is due to confinement effect. Moreover, the edge state is visible in yellow CDs but invisible in blue CDs, indicating that heating process makes the edge state unpronounced. It can be modelled in Fig. 3; the heating process decreases the edge states at valence band until it becomes the same as the core state. Thus, in blue CDs UV-Vis spectra, absorption peak corresponding to $n-\pi^{*}$ transition is invisible. This explanation is supported by the FT-IR spectra that show less $\mathrm{O}=\mathrm{C}=\mathrm{O}, \mathrm{C}-$ $\mathrm{O}$, and $\mathrm{C}-\mathrm{H}$ bonds presence in blue $\mathrm{CDs}$ compared to yellow CDs.

We also propose that surface of CDs also influences the conduction band. As shown in Fig. 3, there is edge state near $\pi^{*}$ state. The existence of the edge state in the conduction band causes variation of emission peak wavelength. The gap between edge and $\pi^{*}$ states reduce as heating process becomes longer. The fact that there is less surface bond $(\mathrm{O}=\mathrm{C}=\mathrm{O}, \mathrm{C}-\mathrm{O}$, and $\mathrm{C}-\mathrm{H})$ in blue $\mathrm{CDs}$ may support this idea.

\section{CONCLUSIONS}

CDs with strong PL properties have been achieved with Aloe vera gel as a primary precursor. Heating durations in the synthesis process play important role in tuning the PL properties. Longer heating duration reduces the oxygen functional group in the CDs surface induces stronger PL and blue-shifting PL peak. These tuneable properties of CDs are potential for bio-labelling and imaging applications. Further investigation about other properties of CDs such as their response to environmental $\mathrm{pH}$ and temperature changing is recommended.

\section{ACKNOWLEDGEMENTS}

Authors would like to thank Department of Physics Education, Yogyakarta State University for supporting this work and to Dr. Imam Santoso from Gajah Madha University who allows authors to use his PL equipment.

\section{REFERENCES}

1. J. Park et al., Nano Lett., 16: 6946 (2016); https://doi.org/10.1021/acs.nanolett.6b03007.

2. M. K. Choi, J. Yang, T. Hyeon, and D. Kim, npj Flex. Electron., 2: 1 (2018); https://doi.org/10.1038/s41528-018-0023-3.

3. E. H. Sargent, Nat. Photonics, 6: 133 (2012).

4. R. Wang et al., Adv. Mater., 30: 1704882 (2018); https://doi.org/10.1002/adma.201704882.

5. $\quad$ B. W. J. Parak et al., Adv. Mater., 14: 882 (2002).

6. W. C. W. Chan, D. J. Maxwell, X. Gao, R. E. Bailey, M. Han, and S. Nie, 
Curr. Opin. Biotechnol., 13: 9 (2002).

7. F. Wang, Z. Xie, H. Zhang, C. Liu, and Y. Zhang, Adv. Funct. Mater., 21: 1031 (2011); https://doi.org/10.1002/adfm.201002279.

8. B. Wang, W. Tang, H. Lu, and Z. Huang, J. Mater. Sci., 50: 5411 (2015); https://doi.org/10.1007/s10853-015-9085-y.

9. M. Havrdova et al., Carbon , 99: 238 (2016); https://doi.org/10.1016/j.carbon.2015.12.027.

10. R. Das, R. Bandyopadhyay, and P. Pramanik, Mater. Today Chem., 8: 96 (2018); https://doi.org/10.1016/j.mtchem.2018.03.003.

11. G. L. Pengju, S. Sushant, Y. Sheng-Tao, S. K. Sonkar, J. Wang, H. Wang, G. E. LeCroy, L. Cao, and Y. P. Sun, J. Mater. Chem. B, 1: 2116 (2013); https://doi.org/10.1039/c3tb00018d.

12. H. Dai, Y. Shi, Y. Wang, Y. Sun, J. Hu, and P. Ni, Sensors Actuators B. Chem., 202: 201 (2014); http://dx.doi.org/10.1016/j.snb.2014.05.058.

13. R. Tabaraki and N. Sadeghinejad, Ecotoxicol. Environ. Saf., 153: 101 (2018); https://doi.org/10.1016/j.ecoenv.2018.01.059.

14. J. A. Jaleel and K. Pramod, J. Control. Release, 269: 302 (2018); https://doi.org/10.1016/j.jconrel.2017.11.027.

15. X. Zhang, Y. Zhang, Y. Wang, S. Kalytchuk, S. V Kershaw, and Y. Wang, ACS Nano, 7: 11234 (2013); https://doi.org/10.1021/nn405017q.

16. V. Arul and M. G. Sethuraman, ACS Omega, 4: 3449 (2019); https://doi.org/10.1021/acsomega.8b03674.

17. H. Choi et al., Nat. Photonics, 7: 732 (2013); https://doi.org/10.1038/nphoton.2013.181.

18. L. Adinarayana et al., J. Mater. Sci. Appl., 3: 83 (2017).

19. G. Huang, X. Chen, C. Wang, H. Zheng, Z. Huang, D. Chen, and H. Xie, RSC Adv., 7: 47840 (2017); https://doi.org/10.1039/C7RA09002A.

20. R. Atchudan, T. Nesakumar, J. Immanuel, S. Perumal, and Y. R. Lee, ACS Omega, 3: 17590 (2018); https://doi.org/10.1021/acsomega.8b02463.

21. S. Chandra et al., Anal. Chim. Acta, 1054: 145 (2019); https://doi.org/10.1016/j.aca.2018.12.024.

22. J. T. Margraf, V. Strauss, D. M. Guldi, and T. Clark, J. Phys. Chem. B, 119: 7258 (2015)

23. S. K. Bhunia, A. Saha, A. R. Maity, S. C. Ray, and N. R. Jana, Sci. Rep., 3: 2473 (2013); https://doi.org/10.1038/srep01473.

24. J. H. Hamman, Molecules, 13: 1599 (2008); https://doi.org/10.3390/molecules13081599.

25. A. Surjushe, R. Vasani, and D. Saple, Indian J. Dermatol., 53: 163 (2008). 